\title{
New Look On Microfinance
}

\author{
Minji Kang
}

\author{
Email: kangminj@usc.edu
}

DOI: 10.26821/IJSRC.9.2.2021.9220

\begin{abstract}
The effectiveness of Microfinance and whether microloan delivers its promises of reducing poverty remains unclear. However, this paper describes how the current limitations need to be understood with the social context to be more effective in helping female clients of microloans.
\end{abstract}

Keywords: Microfinance, Poverty, Effectiveness of Microfinance, Empowering Women

\section{INTRODUCTION}

By definition, microfinance is the provision of financial services to the poor on a sustainable basis (International Labor Organization, 2005). In the early 2000s, microcredit loans emerged as an instrumental tool against combating poverty, laying the foundation for the 2006 Nobel Peace Prize. Unlike former financial services, which inherently excluded those in need, microcredit loans reached the poorest of the poor to provide financial assistance for economic empowerment. In turn, those economically disadvantaged could set up small businesses and repay as they generated income. It broadened the range of financial services and aided by specializing its services towards specific socioeconomic groups who needed it the most. Ultimately, microfinance pioneered new types of banking systems targeted towards impoverished communities, promising poverty alleviation and increased financial services access.

However, unlike the early 2000s hype about the new financial model to cure global poverty, microfinance's popularity declined gradually and almost vanished in the late 2010s. Quantitative researchers have undertaken randomized control trials to examine the effects of microloans, which revealed that "studies do not find clear evidence, or even much in the way of suggestive evidence, of reduction in poverty or substantial improvements in living standards" (Banerjee et al., 2015). This 2015 study conducted by economists at the Massachusetts Institute of Technology revealed limited transformative effects of microcredit for the average borrower. Qualitative research also raised questions about the legitimacy of the repeated microcredit mantra. Lamia Karim, in her book, "Microfinance and Its Discontents" documents how she found contradictions between the believed "rhetoric of microfinance organizations and the lived realities of the women who were situated in dense webs of social and kin obligations and reciprocities that constrained their economic activities" (Karim, 2011). Through testimonial evidence, Karim explains how female borrowers are often bound by familial obligations that restrain free economic activities. Other researchers support Karim's findings as their studies reveal unintended consequences of microfinance on borrowers' lives. As such, microfinance lacks the foundation to be considered a cure-all for the alleviation of poverty.

Nevertheless, conflicting evidence in proving dramatic transformation in the lives' of the poor should not be a sole measure to assess microfinance institutions' effectiveness. Microfinance does hold significance in empowering women through increased ownership of assets and influence on expenditure outcomes (Haile et al., 2012). More accessibility to financial opportunities allows female borrowers to contribute to their household income and results in higher school enrollment rates for their children, which may lead to even more considerable incomes and savings to break the cycle of poverty (Kabeer, 2001). In essence, while microfinance may not be a cure-all to combat poverty, it effectively empowers female borrowers because increased access to financial services results in greater ownership of assets and influence on household expenditures. More investment in education and better health practices due to an increase in income makes a substantial contribution to increasing the overall standard of living for these individuals, which translates into sustainable growth on a societal level.

\section{Why Does Microfinance Fail?}

Perhaps the most important task to fully comprehend why microfinance lost its popularity would be to examine the shortcomings of the system itself. It has been reported that even the CEOs of multinational microfinance institutions admitted: "microfinance does not end poverty, despite all the hype" (Roodman, 2012). The overhype surrounding anecdotal success stories can be powerful in convincing poor men and women to apply for loans only to find themselves in more debt. According to Roodman, the overhype and glorification of microfinance eroded the 
Volume 9 Issue 2 February 2021

constructiveness of microfinance. Rather than building momentum towards helping the poor, developmental programs commercialized to become a lucrative industry. The promises of social entrepreneurship became elusive.

Uncertainty of the effectiveness of microlending is mainly attributable to the incongruence in research findings. For example, a study led by American economist Dean Kalan conducted a study in Manila that proved the effectiveness of microfinance for families over the course of one or two years after receiving the loan. The conclusion of this 2010 study revealed: "no evidence that increased access to credit improves subjective well-being" (Karlan, D., \& Zinman, J., 2010). Another study conducted in Bosnia backs this claim, which showed a boost in the amount of microloan distributed, increasing from \$275 million to $\$ 1$ billion within three years, but slumped $20 \%$ to $\$ 830$ million the next year in 2009 (Augsburg et al., 2015). Therefore, the results are inconsistent with the potential hopes people have for microfinance. Furthermore, studies often yield conflicting results; Khandker's 2005 research in Bangladesh has proven substantial influence of microloans on borrowers' living standards, while Colemen's 2006 study in Thailand suggested otherwise. It is from this incongruence that uncertainty of the effectiveness of microfinance began.

Moreover, the indebtedness of loaners or the inability to repay the loans is another reason that eroded microfinance's hype. According to David/Hulme's 2015 publication on the assessment of microfinance industries, it has been reported that microfinance institutions' local field partners encouraged loaners to take on bigger loans than they could repay and threatened them psychologically and physically. This has been reported more frequently when the local staff members were fairly middle class, educated men, and the borrowers were women who did not receive formal education in South Asia. In Andhra Pradesh, India, these aggressive lending practices in 2010 allegedly became the reason for over 200 microfinance suicides. Repayment plummeted to $10-20 \%$ in the Krishna district and led to heated debate over whether to quash the legitimacy of microcredits altogether (Ghate, 2007). The Krishna District crisis led to the decline of MFI popularity in India, a place that once held great potential for microloans.

The third reason for microfinance failure could be explained by the high-interest rates of average MFL loans that consign borrowers into a vicious cycle of indebtedness. While producing a public image that portrays microfinance institutions as highly accessible with manageable interest rates, borrowers are charged at interest rates too high for them to repay. Grameen bank charges $22 \%$ per annum, while Kiva charges $31 \%$ portfolio interest rates on their clients. As microfinance lending volume expands rapidly, there may be an oversupply of credit, resulting in clients exceeding the debt burden they can manage.

Financial illiteracy also contributes to exacerbating the problem of indebtedness. India's financial literacy rate was shown to be around $20-35 \%$, with half of the surveyed participants not understanding the concept of compound interest rates, and only $14 \%$ of adults could answer questions on risk diversification (Klapper et al., 2012). Bangladesh, which is considered the epicenter of microfinance, has $24 \%$ of the overall population financially literate. The problem here is that most of the countries discussed are the very places where microfinance institutions have thrived historically. However, there is a lack of studies that prove the effectiveness of financial education that these institutions implement in their programs. With the massive numbers of clients they serve worldwideKiva serves more than a million clients worldwidethe extent to which these financial training programs are conducted to help borrowers remains elusive. For instance, Kiva lays out the broad aspects of financial education they practice - from financial planning to credit management - detailed outlines on who conduct such training are not explicit. A lack of financial literacy is correlated with higher debt burdens, incurring more significant fees, loan defaults, and loan delinquency (French, D., \& McKillop, D., 2016). In other words, in an environment where borrowers are under constant financial pressure, lack of basic skills increase the tendency to make bad financial decisions and discourage better organization of finances.

\section{Measuring Microfinance}

However, financial illiteracy is not exclusive to microfinance. Financial illiteracy often offers explanations for poor economic decisions that led to world-class financial crises - the subprime mortgage crisis in 2008 stands as a primary example. Individuals' ability to make informed financial decisions is critical to developing sound personal finance, contributing to a more efficient allocation of financial resources and greater financial stability at both the micro and macro level (Lusardi, A., \& Mitchell, O. S. 2014). However, ignorance about basic financial concepts can be linked to a lack of retirement planning, lack of participation in the stock market, and poor borrowing behavior (Lusardi, A., \& Mitchell, O. S. 2014).

Before the housing crisis, investors created mortgagebacked securities composed of bundles of home loans bought from the banks that issued them to receive periodic payments with interest rates. Investors who were desperate to create more of these MBS ended up loosening their standards and made loans to people with poor credits and loans. Eventually, some institutions employed predatory lending practices to generate mortgages lent without verifying income and offered adjustable mortgages rates which borrowers 
Volume 9 Issue 2 February 2021

could pay initially but quickly inflated beyond their means. Increased default rate and more supply of houses led to the plummeting of house prices, which led to the bankruptcies of big lenders who were dependent on the success of mortgage-backed securities. Multiple studies focused on highlighting the link between financial literacy and failure to make informed decisions to explain the housing crash incident. These studies not only pointed out that it is of little surprise that a lack of financial literacy is found to be associated with poor financial decisions or lower financial well-being but also, individuals with limited financial literacy are prone to take out high-cost mortgages and to have debt problems (Gerardi et al., 2013).

Secondly, the inconsistencies in microfinance studies' effectiveness should not be a parameter to assess the inherent value of microfinance itself. The inherent potential impact of microfinance and measuring its real effectiveness can significantly differ. Microfinance's influence is much more complicated than just measuring the number of loans, the profitability, or loans provided for specific groups of borrowers, such as women (Weber 2013). Therefore, the complexity of measuring effectiveness further multiplies as the definition of "effectiveness" has not been established in the realm of the microfinance literature. Most of the prominent research done on microfinance institutions like Grameen Bank in 2010 concluded the research stating, "As our understanding of the strengths and limitations of various research methods deepens, the research community's ability to answer these critical questions will be enhanced," meaning there are more to be modified in the evaluation process of microfinance itself. The growth of microfinance in Africa, for example, skyrocketed from 2002 to 2012 by more than $1,300 \%$, with a leap in gross loan portfolio from $\$ 600$ million to $\$ 8.4 \%$ billion (Njiraini, 2015). However, unlike the positive outcomes of the 2012 study, a 2015 study concluded that seven randomized evaluations of microcredit products did not increase average income or consumption and neither had a substantial effect on business investments nor profits (Banerjee et al., 2015). Due to a lack of coherence in statistical reliability, case studies present diverging results that do not offer a concrete answer to whether microcredit is a powerful tool to combat poverty. In essence, incongruent results do not indicate microfinance's ineffectiveness but instead reflect the difference in the cultural context where studies have been conducted and methodologies in which researchers employed to conduct their studies.

Perhaps, the incongruent evidence of microfinance's effectiveness can be attributed to differences in cultural aspects of where these studies were conducted. For instance, in more collectivist societies, individuals are more likely to work towards collective goals, whereas autonomy is more valued in more individualistic societies (Oyserman et al., 2002). In his 2010 article, Grameen Credit, Gould argues that the relative success of microfinance institutions in Bangladesh could be attributed to collectivist cultural norms. Trust could be another factor determining the outcome as microcredits imitate informal lending practices that heavily rely on personalized interaction and communal norms. As microfinance institutions heavily rely on personalized interactions and communal norms, their operations should be deeply embedded in a country's social and cultural context (Epstein \& Yuthas, 2011).

For example, microfinance institutions must consider Indonesia's economic reliance on primary industries, including agriculture and fisheries, when setting up repayment plans. Indonesia is one of the world's largest producers and exporters of tree crops such as rubber, copra, palm kernels, palm oil, coffee, cocoa, and species (Ministry of Agriculture, 2001). In addition, with more than 12 million people working in the fishery industry, the nation's water supports over 3,000 bony fish species and more than 850 sharks, rays, and chimeras (The Nature Conservancy). The number of the Indonesian working population in these primary industries substantiates the importance that these industries have on the economy and are also indicative of microfinance strategies that should be implemented. Primary goods are subject to price volatility due to uncontrollable weather conditions or crop pests. If institutions employ a rigid repayment mechanism, it may go so far as to undermine the main objective of empowering these clients as it burdens them to follow an inflexible repayment schedule that does not reflect their reality. These incompatible services with the poor's living patterns, whose economic activities rely on high price vulnerable industries, may deter the cycle out of poverty (Matin et al., 1999).

Religion, ethnic, or cultural practices may also contribute to why certain groups within a community cannot promote microcredit financial service. Building and maintaining a level of trust when different ethnic or religious groups are involved can make providing microfinance services more difficult (Lederwood, 1998). Therefore, it should be noted that cultural differences impact how microfinance services and products can be developed across global regions. In Islamic finance governed by sharia law, money cannot be treated as a commodity (Lederwood, 1998). Money must be used productively in exchange for labor or land with the return based on actual profit or loss, not on the interest rate. When microloans are deemed tools rather than a reasonable return on labor, a clash may arise between the different religious interpretations of sharia law and micro-lending principles. In addition, different interpretations of sharia law across the borders of Middle Eastern countries also demand a detailed study of Islamic cultural practices. While some may view Islamic banking as suitable to implement microfinance, as collaterals are not required 
Volume 9 Issue 2 February 2021

in taking out loans, it divides the risk between the clients and the bank, which narrows the threshold for unserved Muslims to take out loans from these banks. As such, rendering an appropriate model that accurately reflects the religious interpretations of sharia law will be the crucial denominator to the success of microfinance in the Middle East.

\section{Effectiveness of Microfinance}

As limited and flawed mechanisms for measuring its effectiveness, microfinance still offers glimpses of hope that it can help females from underserved communities to take advantage of economic activities. Despite mixed results, quantitative data proves beneficial effects on borrowers, including the most vulnerable communities susceptible to poverty. Women are more likely to be beneficiaries of microfinance loans as they make up approximately $83.4 \%$ or 88.72 million of the most impoverished clients reached by 3552 microfinance institutions operating in developing countries (Daley-Harris, 2009).

Microfinance programs primarily focus on targeting women in developing nations with the expectation that more access to microcredit can advance their empowerment on top of poverty reduction. Several empirical studies conducted in Bangladesh substantiate how microfinance can help female clients to contribute to their household income and increase their assets (Johnson, 2005). Additionally, the increased household income participation has been shown to increase the household expenditure on food and children's' education, especially on school enrollment for girls (Kabeer, 2001). More conspicuously, a lower domestic violence rate was reported with more aceess to microfinance loans for women (Kabeer, 2001; Mayoux, 2001). To examine the extent to which microfinance positively impacted women, one should consider how microfinance institutions like Grameen Bank have performed since its establishment in 1983.

Institutions like Grameen Bank demonstrate how microfinance can not only lift women out of poverty but play a critical role in their empowerment. Grameen Bank (GB) is widely considered one of the world's most successful financial institutions that cater exclusively to the poor. On the Grameen Bank website, it is reported that as of 31 December 1995, an outreach to 9.1 million members, 94 percent of poor women, in 81,677 villages of Bangladesh, reached through 2,568 branches. Cumulative loan disbursements are given as US\$2.66 billion; loans outstanding, according to the balance sheet, amount to $\$ 1.94$ billion, total assets $\$ 3.14$ billion, and 'deposits and other funds' $\$ 2.77$ billion. Many have been deeply impressed by these figures and GB's publicity, particularly since the Microcredit Summit of February 1997 in Washington.
To get a more micro-level understanding of how microfinance can help women, Khan and Noreen's 2012 study has outlined how access to credit socially empowered women in Pakistan (Khan, R. E. A., \& Noreen, S, 2012). The positive impact on women was also substantiated by other case studies in Ghana where the loan utilization by the female borrowers, especially married women, were able to commit themselves to their children's education, become more confident and more assertive, and were more likely to take part in family and community decisions and better able to confront gender inequities (Addai, 2017).

However, there is ample evidence to prove that financial service alone may not be enough to guarantee quality loans to female entrepreneurs and that legal and social measures should be taken cohesively to achieve the ultimate goal of the financial empowerment of female clients. According to the World Bank's study on the microfinance sector in Pakistan, more than twothirds of women borrowers have required a male relative's permission to qualify for any type of loan (Safavian, 2013). Field staffs consider husbands to be the real guarantor of the loan and require their consent and hand-written signatures before female clients can legally take out a loan. Changes in the legal requirements and the procedure of lending could help lower the barriers for women to manage their finances without a third party's intervention. The World Bank Group, for example, has supported the movement to remove legal restrictions embedded in the Democratic Republic of Congo that deterred female clients from making active financial decisions. Reducing genderbased barriers in these financial institutions could set precedents for women to enjoy the benefits of microfinance credits more freely.

Furthermore, while group lending may guarantee a higher repayment rate, it impedes the process of offering financial assistance for female clients in urban areas. Group lending is a strategy MFI institutions concocted to hold clients accountable through a joint repayment system. If a member defaults on her repayment, other group members are responsible for the according costs. While this repayment system seeks to strengthen solidarity among female borrowers to work cooperatively towards the end goal, discrepancies in priorities and opinions between these borrowers may result in inefficiencies. Over 80 percent of female clients of business development services in Pakistan reported that group lending was problematic and did not suit their needs (Safavian, 2013). In essence, these clients are harmed rather than benefited by the group lending system that allows deindividuation, making it difficult to maintain sound credit discipline while the transaction cost for participating may be high. 
Volume 9 Issue 2 February 2021

\section{CONCLUSION}

In conclusion, most of the evidence on the depth of outreach of microfinance institutions suffers from being anecdotally driven. The existing studies do not systematically explain differences in depth of outreach of microfinance institutions, nor do they explicitly explore whether there is a trade-off between the depth of outreach versus the struggle for financial sustainability (Niels Hermes, \& Lensink, R., 2007). The findings of quantitative studies fail to capture a cohesive picture. Most of the studies focus on specific regions when investigating how microcredit benefits certain groups of people. However, it should be noted that while the investigations on the effectiveness of microfinance differ, most studies identify women as the primary beneficiary of MFI loans.

Despite mixed results, quantitative data proves beneficial effects on borrowers, including the most vulnerable communities susceptible to poverty: women. In the end, microcredits are made to help the poorest of the poor by lowering the barriers to financial assistance in underserved communities. Among 140 million clients who have benefited from the service provided by microfinance institutions, more than 80 percent of the clients are female borrowers (Safavian, 2013). Grameen Bank has proven its success through the last 30 years of its service, where the average default rate of the loans was 2 percent compared to the 9 percent that Bangladesh commercial banks suffer (Hossain, 2020). And while the effects of microfinance loans on women prove to be beneficial, case studies show that lending practice reform must be incorporated for better effectiveness. While intended to help female clients through targeted lending, financial institutions are not able to change social climates which are unsupportive of female empowerment. Gender-based barriers still exist in countries where husbands are deemed real guarantors of the loans, and group lending practices do not suit urban clients' interests. Therefore, amendments of these socioeconomic policies and the social awareness that allows the clients to be the beneficiaries of micro-loans must be included for better microlending practices that can suit female borrowers' reality.

\section{REFERENCES}

[1]. Addai, B. (2017). Women empowerment through microfinance: Empirical evidence from Ghana. Journal of finance and accounting, 5(1), 1-11.

[2]. Augsburg, B., De Haas, R., Harmgart, H., \& Meghir, C. (2015). The impacts of microcredit: Evidence from Bosnia and Herzegovina. American Economic Journal: Applied Economics, 7(1), 183-203.
[3]. Banerjee, A., Duflo, E., Glennerster, R., \& Kinnan, C. (2015). The miracle of microfinance? Evidence from a randomized evaluation. American Economic Journal: Applied Economics, 7(1), 22-53.

[4]. Collins, D., Morduch, J., Rutherford, S., \& Ruthven, O. (2009). Portfolios of the poor: how the world's poor live on $\$ 2$ a day. Princeton University Press.

[5]. Epstein, M. J., \& Yuthas, K. (2011). The critical role of trust in microfinance success: Identifying problems and solutions. Journal of Developmental Entrepreneurship, 16(04), 477-497.

[6]. French, D., \& McKillop, D. (2016). Financial literacy and over-indebtedness in low-income households. International Review of Financial Analysis, 48, 1-11.

[7]. Gerardi, K., Goette, L., \& Meier, S. (2013). Numerical ability predicts mortgage default. Proceedings of the National Academy of Sciences, 110(28), 11267-11271.

\section{$\checkmark$}

[8]. Ghate, Prabhu. (2007). Consumer Protection in Indian Microfinance: Lessons from Andhra Pradesh and the Microfinance Bill. Economic and Political Weekly. 42. 1176-1184. 10.2307/4419417.

[9]. Grameen Bank. (2018). Balance sheet (19832018) in USD. Grameen Bank. http://www.grameen.com/data-andreport/balance-sheet-1983-2016-in-usd/.

[10]. Haile, H. B., Bock, B., \& Folmer, H. (2012, July). Microfinance and female empowerment: Do institutions matter?. In Women's studies international forum (Vol. 35, No. 4, pp. 256265). Pergamon.

[11]. Harris, S. D. (2009). State of the microcredit summit campaign. Washington, District of Columbia: Microcredit Summit Campaign, 15.

[12]. Hossain, S. (2020, February 17). 14 banks cut default loans by 30pc,NRBC alone 77pc. The BusinessStandard. https://tbsnews.net/eco nomy/banking/14-banks-cut-default-loans30pc-nrbc-alone-77pc-45301.

[13]. Hulme, D., \& Arun, T. (2011). What's wrong and right with microfinance. Economic and Political Weekly, 23-26. 
Volume 9 Issue 2 February 2021

[14]. International Labour Organization. (2005). ILO Research Guides: Microfinance. Home Microfinance - ILO Research Guides at http://libguides.ilo.org/microfinance-en.

[15]. Johnson,S. (2005). Gender relations, empowerment and microcredit: moving on from a lost decade. The European Journal of Development Research, 17(2), 224-248.

[16]. Kabeer, N. (2001). Conflicts over credit: reevaluating the empowerment potential of loans to women in rural Bangladesh. World development, 29(1), 63-84.

[17]. Karim, L. (2011). Microfinance and its discontents: Women in debt in Bangladesh. U of Minnesota Press.

[18]. Karlan, D., \& Zinman, J. (2010). Expanding credit access: Using randomized supply decisions to estimate the impacts. The Review of Financial Studies, 23(1), 433-464.

[19]. Khan, R. E. A., \& Noreen, S. (2012). Microfinance and women empowerment: A case study of District Bahawalpur (Pakistan). African Journal of Business Management, 6(12), 4514-4521.

[20]. Klapper, L., Lusardi, A., \& Panos, G. A. (2012). Financial literacy and the financial crisis. The World Bank.

[21]. Ledgerwood, J. (1998). Microfinance handbook: An institutional and financial perspective. The World Bank.

[22]. Lusardi, A., \& Mitchell, O. S. (2014). The Economic Importance of Financial Literacy: Theory and Evidence. Journal of economic literature,52(1),544.https://doi.org/10.1257/jel.52.1.5

[23]. Matin, I., Hulme, D., \& Rutherford, S. (2002). Finance for the poor: from microcredit to microfinancial services. Journal of international development, 14(2), 273-294.
[24]. Mayoux, L. (2001). Tackling the down side: Social capital, women's empowerment and micro- finance in Cameroon. Development and change, 32(3), 435-464.

[25]. Ministry of Agriculture, Republic of Indonesia. (2001). Agricultural development in Indonesia 1996-2000. Jakarta.

[26]. Niels Hermes, \& Lensink, R. (2007). The empirics of microfinance: What do we know? The Economic Journal,117(517), F1-F10. Retrieved November 30, 2020, from http://www.jstor.org/stable/4625473

[27]. Njiraini, J. (2015). Microfinance: Good for the poor? | Africa Renewal. United Nations. https://www.un.org/africarenewal/magazine/a ugust-2015/microfinance-good-poor.

[28]. Oyserman, D., Coon, H. M., \& Kemmelmeier, M. (2002). Rethinking individualism and collectivism: evaluation of theoretical assumptions and meta-analyses. Psychological bulletin, 128(1), 3.

[29]. Roodman, D. (2012). Due diligence: An impertinent inquiry into microfinance. CGD Books.

[30]. Safavian, M., \& Haq, A. (2013). Are Pakistan's women entrepreneurs being served by the microfinance sector?. The World Bank.

[31]. The Nature Conservancy. Indonesia Fisheries. The Nature Conservancy.https://www.nature.org/enus/about-us/where-we-work/asiapacific/indonesia/stories-inindonesia/indonesia-fisheries/.

[32]. Weber, O. (2013). Impact measurement in microfinance: Is the measurement of the social return on investment an innovation in microfinance?. Journal of Innovation Economics Management, (1), 149-171. 